\title{
Impact of Helminth Infections on Female Reproductive Health and Associated Diseases
}

\author{
Alisha Chetty ${ }^{1 *}$, Millicent A. Omondi ${ }^{1}$, Claire Butters ${ }^{1}$, Katherine Ann Smith ${ }^{1,2}$, \\ Gnatoulma Katawa ${ }^{3}$, Manuel Ritter ${ }^{4}$, Laura Layland ${ }^{4 *}$ and William Horsnell ${ }^{1,5 *}$ \\ 1 Institute of Infectious Disease and Molecular Medicine and Division of Immunology, University of Cape Town, Cape Town, \\ South Africa, 2 School of Biosciences, Cardiff University, Cardiff, United Kingdom, ${ }^{3}$ Ecole Supérieure des Techniques \\ Biologiques et Alimentaires, Université de Lomé, Lomé, Togo, ${ }^{4}$ Institute for Medical Microbiology, Immunology and \\ Parasitology (IMMIP), University Hospital Bonn (UKB), Bonn, Germany, ${ }^{5}$ Institute of Immunology and Immunotherapy, \\ University of Birmingham, Birmingham, United Kingdom
}

OPEN ACCESS

Edited by:

Mark C. Siracusa,

Rutgers Biomedical and Health

Sciences, United States

Reviewed by:

Meera G. Nair,

University of California, Riverside,

United States

Elia Tait Wojno,

Cornell University, United States

*Correspondence: Alisha Chetty alisha.chetty@uct.ac.za Laura Layland laura.layland@sbcomputing.de William Horsnell wghorsnel/@gmail.com

Specialty section:

This article was submitted to Microbial Immunology,

a section of the journal

Frontiers in Immunology

Received: 29 June 2020 Accepted: 27 October 2020 Published: 23 November 2020

Citation:

Chetty A, Omondi MA, Butters $C$, Smith KA, Katawa G, Ritter M, Layland $L$ and Horsnell W (2020) Impact of Helminth Infections on Female Reproductive Health and Associated Diseases.

Front. Immunol. 11:577516. doi: 10.3389/fimmu.2020.577516
A growing body of knowledge exists on the influence of helminth infections on allergies and unrelated infections in the lung and gastrointestinal (Gl) mucosa. However, the bystander effects of helminth infections on the female genital mucosa and reproductive health is understudied but important considering the high prevalence of helminth exposure and sexually transmitted infections in low- and middle-income countries (LMICs). In this review, we explore current knowledge about the direct and systemic effects of helminth infections on unrelated diseases. We summarize host diseasecontrolling immunity of important sexually transmitted infections and introduce the limited knowledge of how helminths infections directly cause pathology to female reproductive tract (FRT), alter susceptibility to sexually transmitted infections and reproduction. We also review work by others on type 2 immunity in the FRT and hypothesize how these insights may guide future work to help understand how helminths alter FRT health.

Keywords: Helminths, female reproductive tract, sexually transmitted infections, fertility, Systemic immunity

\section{BURDEN OF DISEASE}

Helminth infections are widespread and are characterized by sophisticated host immune modulation and evasion. Helminth infections are a global health concern, with more than 1.7 billion affected worldwide, particularly in tropical and subtropical regions (1). A feature of helminth infections are the parasites' ability to alter immunity and susceptibility to unrelated diseases (2-7). Of particular interest is the potential impact of helminth immune-regulation on susceptibility to sexually transmitted infections (STIs), given their high incidence in developing regions and detrimental impact on public health (8). For example, Ivan et al. (9) studied a cohort of 328 Rwandan pregnant women on anti-retroviral therapy, $38 \%$ of whom were stool positive for helminth infections (9). Mkhize-Kwitshana et al. (10) reported $66 \%$ of HIV+ study participants from an helminth endemic region of South Africa, were helminth egg positive and/or helminthspecific IgE seropositive (10). Likewise, Abossie and Petros (11) reported 68\% of study participants in Ethiopia were co-infected with helminths and HIV, 35\% were women (11). In this review we 
address how the geographical overlap between helminth exposure and STIs can result in parasite-induced changes to female reproductive health (12-14).

\section{HELMINTH IMMUNITY}

Host immunity to helminths has been studied in depth using mouse models reflective of human infection and immunity (1518). Typically, helminths induce a type 2-skewed immune response, associated with the production of the canonical cytokines interleukin (IL)-4, IL-5, and IL-13 (19-26). These cytokines amplify alternatively activated macrophages (AAMs; M2) (27-29), eosinophilia (30-32), smooth muscle contraction and goblet cell hyperplasia; cellular and physiological responses that underlie the 'weep and sweep' worm expulsion from the intestine $(21,23,24,26,33,34)$. Consistent with in vivo studies, epidemiological studies also report type 2-biased immune responses in humans infected with roundworm Ascaris lumbricoides (35-37), whipworm Trichuris trichiura (36-38), and hookworm Necator americanus (39). Furthermore, experimental infections of participants with hookworm has been shown to result in strong mucosal and systemic type 2 cytokine responses (40). Helminth infections also elicit regulatory immune responses, characterized by transforming growth factor- $\beta$ (TGF- $\beta$ ), IL-10 and expansion of FoxP3expressing regulatory $\mathrm{T}$ cells, involved in immune polarization and controlling inflammation (2, 41-48).

Antagonism between type 1 and type 2 immunity is central to our understanding of the $\underline{T} \underline{h}$ elper (Th) $\underline{1}$ cells (Th1)- $\underline{T} \underline{\text { helper }} \underline{2}$ cells (Th2) immune paradigm: Mosmann et al., first described Th1 and Th2 $\mathrm{CD}^{+} \mathrm{T}$ cell differentiation and cytokine responses $(49,50)$, and Fernandez-Botran et al. (51) first demonstrated Th subtype regulation of each other (51). Furthermore, Reese et al. (52) demonstrated that IL-4 and STAT6 signaling can competitively inhibit interferon (IFN)- $\boldsymbol{\gamma}$ production (52). This paradigm has been expanded beyond $\mathrm{T}$ cell responses, as what is known as type 1 and type 2 immunity and regulation. For example, AAMs are a key feature of helminth infection induced by IL-4, -13 and -10 . AAMs synthesize high levels of the enzyme arginase-1, which inhibits nitric oxide (NO) production (53). In addition, AAMs downregulate inflammatory Th1 immune responses mediated by TGF- $\beta$ (54), which induce the development of regulatory $\mathrm{T}$ cells (41). Considering the opposing responses of type 1 and type 2 immunity, it is hypothesized that canonical type 2 immunity induced by helminths, can influence Th1- and Th17-mediated immune protection against STIs in the female reproductive tract (FRT).

\section{HELMINTH-INDUCED IMMUNE MODULATION}

Co-evolution of parasitic worms with the host is thought to have resulted in their ability to evade host's immunity through highly sophisticated responses. Helminths actively promote the expansion of regulatory $\mathrm{T}$ cell populations, promoting helminth persistence as well as host survival following infection (41, 44, 45, 55, 56). This can be achieved by the helminths release of excretory/secretory products, which effectively target and inhibit specific components of anti-parasite immune mechanisms or induce favorable immune regulation (43). For example, Heligmosomoides polygyrus excretory/secretory products (HES) contain a TGF- $\beta$ mimic, the importance of this is supported by blockade of HES TGF- $\beta$ mimic in vivo resulting in parasite expulsion in susceptible C57BL/6 mice (41). Bancroft et al. (57) recently identified the immunomodulatory molecule $\mathrm{p} 43$, a major secreted protein by murine whipworm T. muris, which binds to and inhibits IL-13 activity (57). Helminth-induced immune modulation benefits parasite survival by supporting asymptomatic or chronic infections. This has been demonstrated by individuals with asymptomatic lymphatic filariasis who display regulatory $\mathrm{T}$ and $\mathrm{B}$ cell responses (58), as well as skewed Th2 and regulatory $\mathrm{T}$ cell cytokine profiles i.e. favorable IL-4 and TGF- $\beta$, over IFN- $\gamma$ and IL-17 production (46, 59-61). Alternatively, symptomatic patients had dominant pro-inflammatory responses, i.e. Th1, Th17 inflammatory responses and uncontrolled Th2 responses, resulting in immune-mediated damage of colonized tissue leading to severe symptoms like dermatitis in hyperreactive onchocerciasis or elephantiasis in lymphatic filariasis $(62,63)$.

Importantly, helminth-induced immune modulation has bystander effects on unrelated conditions such as allergies, autoimmune and inflammatory disorders, and unrelated infections. McSorley et al. (2) reported the suppression of type 2 allergic lung inflammation from treatment with HES (2), associated with TGF- $\beta$-like activity (41). Furthermore, Johnston et al. (42) demonstrated the suppression of skin allograft rejection by treatment with a TGF- $\beta$ mimic isolated from HES (42). In support, Li et al. (64) demonstrated suppression of allograft rejection with $H$. polygyrus-induced Th2 and regulatory $\mathrm{T}$ cell bystander immunity (64). Recombinant hookworm anti-inflammatory proteins have been shown to reduce inflammation during experimental colitis (65) and asthma (66), associated with the induction of regulatory $\mathrm{T}$ cells. Layland et al. (67) demonstrated the suppression of allergic airway inflammation mediated by $S$. mansoni-induced regulatory T cells in vivo (67). Furthermore, Straubinger et al. (68) showed reduced susceptibility to ovalbumin (OVA)-induced allergic airway inflammation in mice born to mothers infected with $S$. mansoni during pregnancy. Osbourn et al. (69) described the ability of $\underline{H}$. polygyrus Alarmin Release Inhibitor (HpARI) secreted protein to bind to and suppress IL-33 activity, reducing ILC2 and eosinophil responses, and promoting parasite survival (69). Interestingly, Zaiss et al. (70) demonstrated that infection with GI $H$. polygyrus resulted in changes to host intestinal microbiota and increased microbialderived short chain fatty acids, which contributed to helminthinduced suppression of allergic lung inflammation (70). Conversely, Pinelli et al. (71) reported exacerbated ova-induced 
allergic airway inflammation in mice infected with Toxocara canis (71). In humans, Jõgi et al. (5) reported increased risk of allergy manifestations in Norwegian children with anti-T. canis IgG4 seropositivity (5).

In addition to modulation of allergies and autoimmunity, Darby et al. (72) recently demonstrated how pre-conception maternal helminth exposure influences offspring immunity to helminth infection. Prior murine hookworm, Nippostrongylus brasiliensis infection imprinted Th2 immunity in female mice, which was transferred via breast milk and conferred protection against the parasite in their offspring. Protection was associated with maternally-derived Th2 primed $\mathrm{CD} 4^{+} \mathrm{T}$ cells (72). Helminth-induced bystander immunity has also been implicated in altered vaccine responses (73-77) and immunity to unrelated infections. This highlights the potential significance of a transgenerational axis of influence on immunity by helminth infections.

Helminth-induced bystander immunity has also been implicated in altered vaccine responses and immunity to unrelated infections (73-77). For example, mouse infection with $T$. spiralis and $H$. polygyrus can impair immunity to murine norovirus (MNV) in the co-colonized intestine, mediated through impaired type 1 responses by type 2 activation of macrophages (78). Changes to lymphoid lineage function are demonstrated by Rolot et al. (7), who show helminth-mediated expansion of virtual memory $\mathrm{CD}^{+} \mathrm{T}$ cells which enhance control of subsequent murine $\gamma$-HV respiratory infection (7). McFarlane et al. (79) showed that infection with murine nematode $H$. polygyrus, altered gut microbiota, which systemically increased proinflammatory type I IFN, and protected against subsequent respiratory viral infection (79). Additionally, in vivo infection with $T$. spiralis reduced pathological inflammation of the airways following influenza $\mathrm{A}$ virus infection (80). Helminth infection also impacts on control of bacterial infections. $N$. brasiliensis infections have been shown to impair natural and vaccine elicited $\mathrm{T}$ cell and $\mathrm{B}$ cell responses against Salmonella typhimurium infection in vivo (4). Protection against bacterial infections has also been reported; with reduced pulmonary mycobacterial burdens during concurrent nematode infection in mice, that required helminth-modified alveolar macrophage responses (3). Human studies have also identified helminth-associated changes to myeloid responses that relate to protection against MTb. For example, a negative association between hookworm infection and latent Mtb infection in Nepalese immigrants to the UK, was associated with elevated eosinophil numbers (6). Coincidence of filarial infection has also been associated with moderate protective immunity during latent Mtb infection $(62,81)$ and in a recent study, $S$. stercoralis infection in latent tuberculosis patients, was associated with down-regulated chemokine responses (82). Associations between soil-transmitted helminth (STH) infection and higher risk of concurrent bacterial and protozoal infections, and lower risk of concurrent viral infections in children and adults have also been reported (83). Recent studies have also demonstrated that prior nematode infection can confer resistance to subsequent infection by a different nematode species $(84,85)$. Together this existing body of work shows that helminths infections can have diverse influences on unrelated disease at sites distal to the anatomical location of the helminth in the host.

\section{HELMINTHS, FEMALE REPRODUCTIVE TRACT, AND SUSCEPTIBILITY TO STIS}

Immune imprinting on helminth infected hosts is therefore a feature of tissues not colonized by the parasite (86), including the FRT (87). The impact of helminth infection on immunity in the FRT and subsequent immune responses to sexually transmitted infections is not well studied, but it is apparent that significant effects on disease control in the FRT are likely.

\section{Immune Control of STIs}

The vaginal mucosa, the entry point for most STIs, is a unique and dynamic mucosal site under the cyclic influence of female sex hormones, and is made up of stratified squamous epithelial, lined by mucous, commensal bacteria and other anti-microbial defenses (88-91). In addition, the vaginal submucosa is surveyed by resident immune cells such as dendritic cells (DCs), which mount the response against invading pathogens (92-95). Host immune control of STIs is strongly correlated with the pattern of cytokine production in the host. Differential activation of Th1 cells, producing IL- 2 and IFN- $\gamma$, mediate cellular immune responses, whereas Th2-like cells producing IL-4, IL-5, and IL13, facilitate humoral immunity (96). Persistence of STIs can also be influenced by the production of IL-10 (97) and activation of regulatory $\mathrm{T}$ cells (98). While many STIs are initially asymptomatic, lack of treatment can result in an increased risk of acquiring another STI, infertility, organ damage, cancer, or death.

The most common sexually transmitted viral infections (STVIs) of the FRT are $\underline{\text { Herpes }}$ Simplex Virus type II (HSV-2), Human Papillomavirus (HPV) and $\underline{H}$ uman Immunodeficiency Virus (HIV). Control of STVIs is typically associated with type 1 immune responses $(99,100)$. With the exception of HIV, killing of virally infected cells requires Th1 polarization of $\mathrm{CD} 4^{+} \mathrm{T}$ cells (101), production of type 1 cytokines such as IFN-gamma (IFN- $\gamma)(102,103)$ and cytotoxic T cell responses (104-106) (Figure 1). Th1 immunity is also critical for early control of HIV, however, this response is insufficient to resolve infection (110), due to the virus' ability to rapidly mutate and evade $\mathrm{CD}^{+} \mathrm{T}$ cell responses (107). Pre-existing inflammation and increased presence of $\mathrm{CD}^{+}$target $\mathrm{T}$ cells in the FRT are major risk factors for increased susceptibility to HIV infection (111). Elimination of $\mathrm{CD}^{+} \mathrm{T}$ cells by HIV is a hallmark of acquired immune deficiency syndrome (AIDS), resulting in increased susceptibility to opportunistic infections (112) and viralassociated cancers (113).

Similarly to STVIs, bacterial infections of the FRT require a Th1 and/or Th17 response to clear the infection $(114,115)$. Chlamydia trachomatis is a common bacterial STI worldwide, with women carrying the burden of this disease (116). IFN- $\gamma$ 


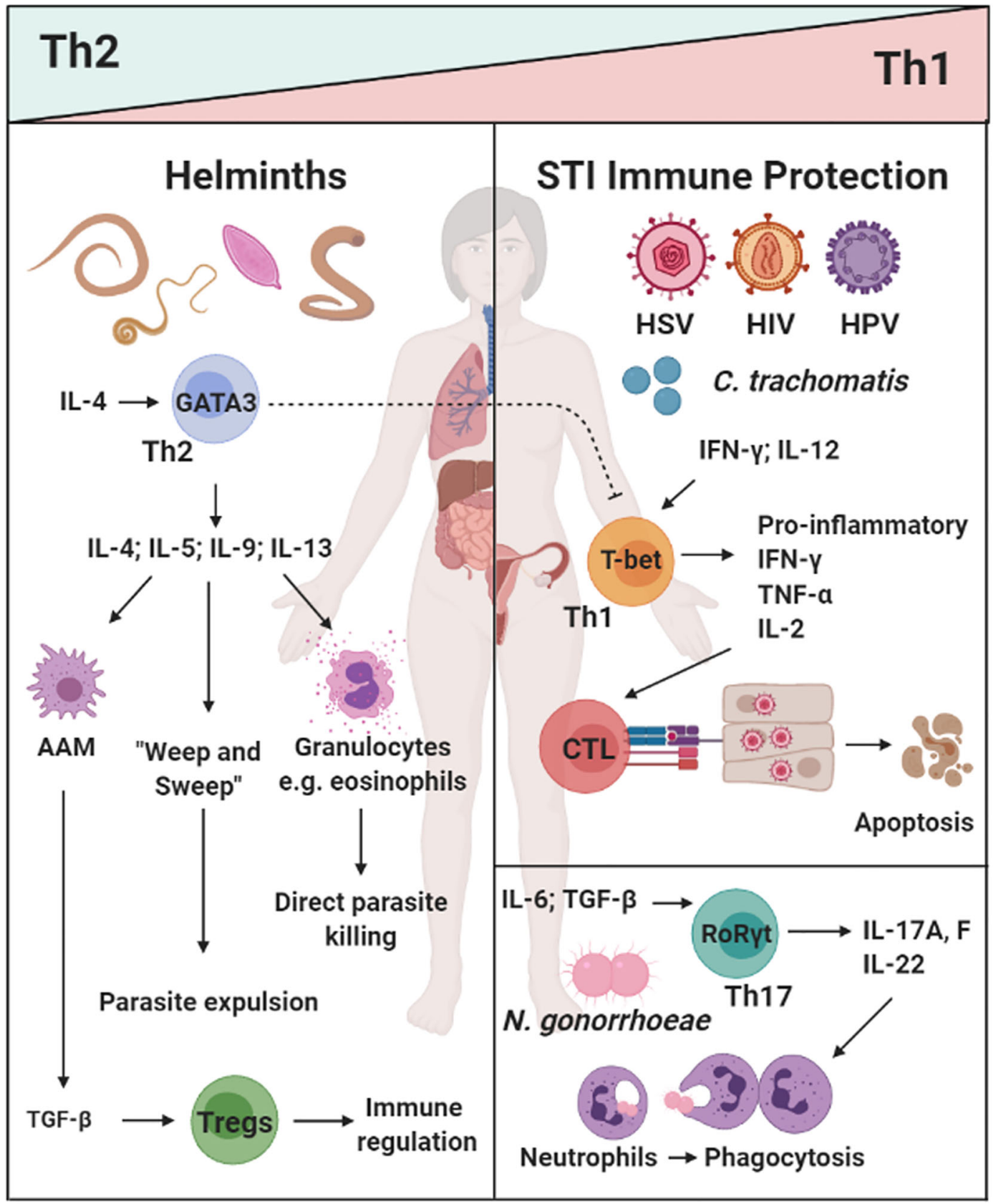

FIGURE 1 | The dichotomy of helminth-induced Th2/type 2 and regulatory immunity, and protective responses against sexually transmitted infections (STIs) in the female reproductive tract (FRT): Helminth infections (e.g. A lumbricodes, T. trichiura, Schistome eggs) commonly induce a potent Th2/type 2 immune response characterized by type 2 cytokines IL-4, IL-9, and IL-13, which induce a potent type 2 effector cells and functions (e.g. eosinophils, alternatively activated

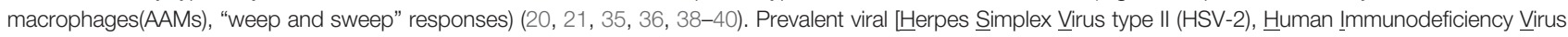
(HIV), and Human Papillomavirus (HPV)] and bacterial (C. tranchomatis and N. gonorrhoeae) vaginal infection are a serious health concern for women in low- and middle-income countries (LMICS). Protective immunity against these pathogens can be classified a Th1/type 1 and Th17 responses i.e. cytotoxic killing of infected cells or phagocytosis of extracellular pathogens (101-107-109). How helminth exposure and immune modulation may influence susceptibility and control of STIs, is not fully understood. Created with BioRender.com.

production by $\mathrm{Th} 1 \mathrm{CD} 4^{+} \mathrm{T}$ cells have been shown to be important for the resolution of C. trachomatis infections (117, 118). Cytotoxic T lymphocyte (CTL) responses are not required for clearance of this infection and instead have been shown to promote tissue pathology in the upper genital tract $(108,109)$. Another common bacterial STI is Neisseria gonorroeae, the causative agent of gonorrhea. In a murine model of infection, Th17 immune responses were shown to be favorable for 
N. gonorrhoeae clearance (114). Considering the established counterbalance between Th2/Treg immunity and Th1/Th17 responses $(50,52,119,120)$, it is important to understand the consequence of helminth-induced immunity on susceptibility to co-endemic STIs (Figure 1).

\section{Genital Schistosomiasis}

Schistosoma haematobium infections have profound effects on female genital health. S. haematobium larvae (cercariae) emerge from aquatic snails and infect the human host through skin penetration. The larvae develop into schistosomula and migrate through the vasculature. Eventually, these mature into adult parasites, pair up and reside for years in the pelvic venous plexus. S. haematobium eggs produced here lodge in the urinary bladder wall and FRT, causing urogenital schistosomiasis (121). In chronically infected individuals, vaginal pathology here is acute with reported itching, pain, hematuria and ulceration in $S$. haematobium-infected individuals (122-125). Pathology is driven by eggs traversing host tissue and the formation of calcified granulomas in the female urinary and reproductive tract. The World Health Organization (WHO) International Agency for

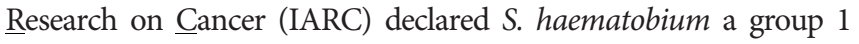
carcinogen, as the correlation between urogenital schistosomiasis and the occurrence of bladder cancer has been extensively proven (126).

In the mouse model of urinary schistosomiasis, injection of eggs into the urinary bladder results in formation of a granuloma around the eggs made up of neutrophils, eosinophils and macrophages, as well as the onset of fibrosis in the surrounding bladder tissue (127). Furthermore, in this model S. haematobium eggs induced a strong type-2 response characterized by eosinophilia and elevated IL-4, IL-13 and IL-5 in the tissue surrounding the eggs. A compromised FRT epithelium is associated with increased HIV risk (128). The bystander tissue damage resulting from S. haematobium egg-induced inflammation $(129,130)$, increased immune activation (131) and lesions in the FRT is reasonably hypothesized to increase host risk of HIV infection, by providing routes for viral entry and increased number of target cells at the site of infection (132) (Figure 2). Furthermore, the type 2 response induced during $S$. haematobium infection (127) may dampen type 1 responses required for protection against viral pathogens such as HIV. These hypotheses are supported by clinical findings, where women infected with $S$. haematobium may have up to a 3-fold increased risk of acquiring HIV (133-135).

Following treatment with the anti-helminthic drug, praziquantel, the immune response in treated individuals shifts from a type 2 and regulatory $\mathrm{T}$ cell immune response (131, 136, $137)$ to a pro-inflammatory state, with elevated levels of egg antigen-specific TNF- $\alpha$, IL-6, IFN- $\gamma$, IL-12p70, IL- 8 and Th17 cytokines (IL-17, IL-21, and IL-23) post-treatment (138). If this inflammatory state results in reduced susceptibility to HIV infection is yet to be explored.

\section{Filariasis}

Filarial-driven immune modulation (i.e. induction of Th2, regulatory immune responses and suppression of inflammatory/
Th1 responses) may increase susceptibility to viral and bacterial infections in the FRT, as Th1/inflammatory responses are important for the defense against these pathogens $(139,140)$. This is supported by identification of an association between infection with the filarial nematode Wuchereria bancrofti and increased risk of HIV infection (141). This increased HIV susceptibility may be associated with systemic increase in proportions of $\mathrm{CD}^{+} \mathrm{T}$ cells expressing HLA-DR and HLA-DR/ CD38, as well as effector memory $\mathrm{CD}^{+}{ }^{+} \mathrm{T}$ cells in lymphatic filariasis patients, i.e. an increase in HIV target cells in these patients (142). This supports in vitro findings demonstrating increased HIV infection of PBMC from lymphatic filariasis patients in comparison to uninfected individuals (12). Increased inflammation has also been reported in lymphatic filariasis patients $(62,143)$, with systemic IL-17 and IFN- $\gamma$ elevated in response to PBMC stimulation with filarial antigen in these individuals. With chronic filarial infections, a type 2 immune signature, i.e. elevated IL-4 and IL-5, is detected in antigen-stimulated host PBMCs (143, 144). In contrast to schistosomiasis, regulatory $T$ cells were reduced in lymphatic filariasis cases $(62,144)$ however type 1 responses (IFN- $\gamma$ production) were suppressed in these patients (144). These studies suggest that chronic filarial infections could alter susceptibility to common FRT pathogens requiring type 1mediated immune control. Surprisingly, genital manifestations of $W$. bancrofti infection have not been associated with any changes to fertility or pathology in the FRT (145).

\section{Soil-Transmitted Helminths}

Unlike schistosomiasis that causes direct pathology to the FRT, evidence has emerged of the potential systemic effect of helminths at sites that are not colonized by these pathogens. In a STH endemic region of Peru, Gravitt et al. (87) reported an increased prevalence of HPV among older women (30-45 years old) infected with STHs, which included T. trichiura, A. lumbricoides, Ancylostoma duodenale and Strongyloides stercoralis. Importantly, the life cycle of these helminths does not involve any larval transit through, or egg deposition in the FRT. The type 2 cytokine IL- 4 was detected in cervicovaginal lavages of these women and IL-4 levels correlated positively with other cytokines involved in anti-helminth immunity; IL-25, IL21, IL-5, IL-10, IL-8, and IL-31 (87). The authors hypothesized that the increased HPV prevalence among older women in STHendemic regions, is mediated by helminth-induced immune regulation which may impair viral control, supported by a in vivo studies which demonstrate IL-4-mediated impairment of anti-viral immunity $(52,78,146)$ (Figure 3). This study therefore suggests a systemic skewing of the immune response towards a type 2 phenotype detectable in the FRT impairing host ability to control HPV via type 1-mediated mechanisms. In contrast, murine hookworm $N$. brasiliensis antigen has been shown to inhibit HPV-16 pseudovirion uptake by human cervical cell lines. Furthermore, murine hookworm antigen exposure and in vivo infection decreased expression of cell surface vimentin or total vimentin expression in the cell line or the FRT, respectively (152). Cell surface vimentin has previously been described as a restriction factor that mediates internalization of $\mathrm{HPV}$ pseudovirion particles (153). This suggests that helminth 


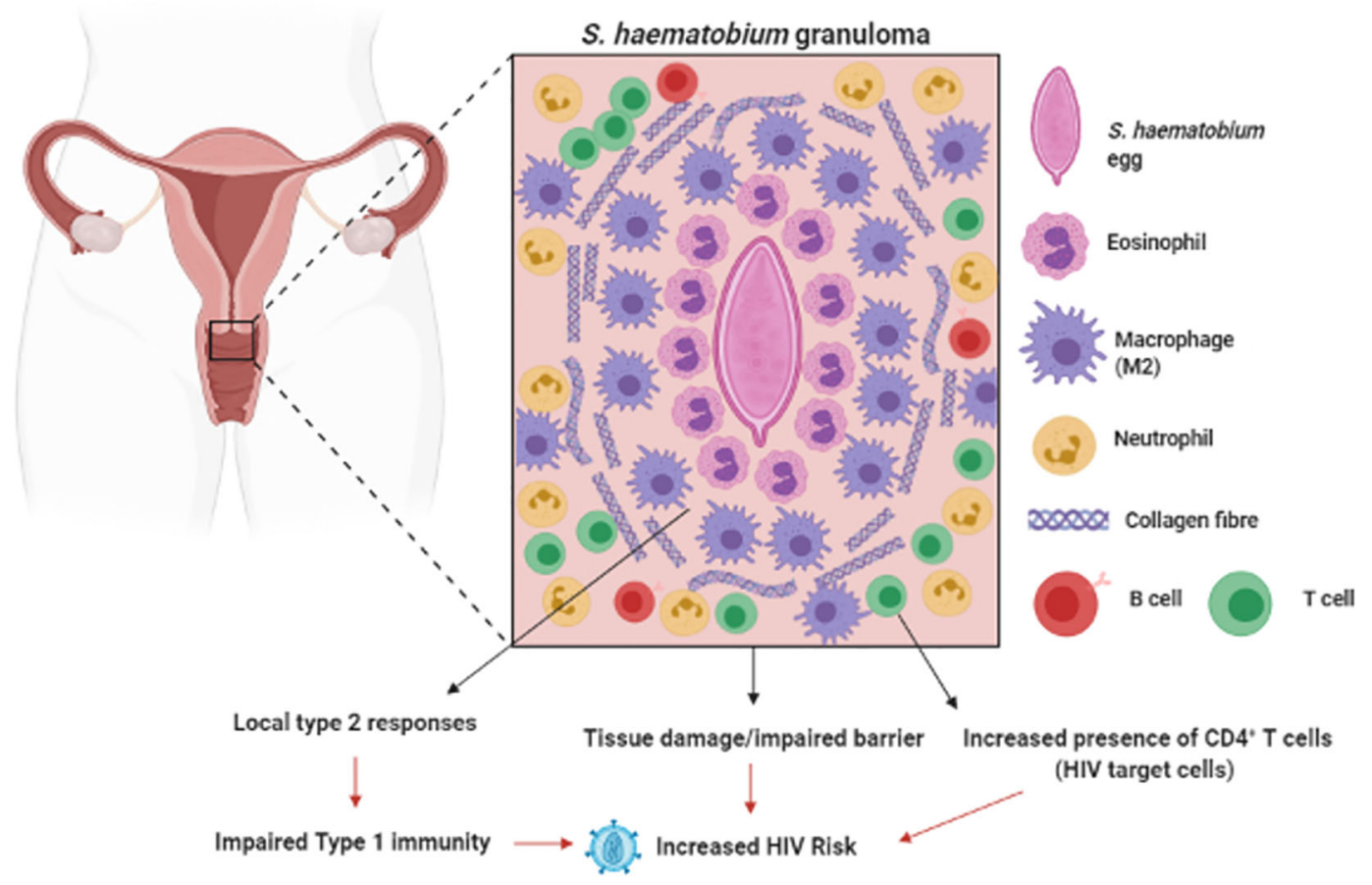

FIGURE 2 | Genital Schistosomiasis: In S. haematobium infected women, eggs can become lodged in the cervix, resulting in inflammation around the schistosome eggs (granula) and bystanders tissue damage. Genital schistosomiasis is common and can impair vaginal immunity and increase Human Immunodeficiency Virus (HIV) risk (129-133). Created with BioRender.com.

exposure may alter cervical epithelial susceptibility to HPV infection. Further, N. brasiliensis L3 somatic antigen decreased migration of cervical cancer cells in motility assays, suggesting a possible downmodulation of cancer cell metastasis by this helminth. Further studies are required to fully understand the complex consequences of helminth infection on HPV infection and pathogenesis.

\section{HPV, Cancer, and Type 2 Immunity}

Persistent HPV strains evade protective host immune responses, which are the first steps to the development of high-grade cervical lesions and cancer (154-156). Interestingly, type 1/type 2 antagonism can be manipulated by oncogenic HPV, to suppress anti-viral responses, promote persistence and tumor development (157). For example, Lepique et al. (147) described an association between M2-like macrophages and the suppression of anti-tumor responses and tumor progression during HPV-related cancer (147). Here, they identified tumor-associated macrophages (TAMs) as a dominate population in tumors, with high baseline Arginase I and IL-10 expression, and low iNOS activity, when stimulated with LPS/IFN- $\gamma$. Additionally, Petrillo et al. (148) reported a correlation between increased ratio of M2:M1 macrophages and poor responses to treatment and survival (148). Regulatory cytokines IL-10, TGF- $\beta$ and prostaglandin E2 $\left(\mathrm{PGE}_{2}\right)$ produced by M2-like TAMs, promote the accumulation of regulatory $\mathrm{T}$ cells, which are associated with viral persistence and tumor development (158-160). Production of type 2 cytokines (e.g. IL-4, IL-13) by M2-like TAMs promotes Th2 polarization, reducing Th1 and CTL responses (149, 161-164). Moreover, Xie et al. (150) reported high levels of eosinophils in cervical cancer lesions and demonstrated that thymic stromal lymphopoietin (TSLP)-mediated eosinophil infiltration and activation promoted proliferation of cancer cells in vitro (150). Considering the significance of type1/type 2 imbalances during HPV persistence and related cancer progression, we hypothesize that helminthinduced type 2 immunity may impair anti-viral and anti-tumor immune responses, resulting in the promotion of tumor progression in the FRT (Figure 3).

\section{Type 2 Immunity in the FRT}

The role of type 2 immunity in modulating immune responses in the FRT has been demonstrated by Oh et al. (165), where induction of the type 2-associated 'alarmin' IL-33 in the genital mucosa, increased susceptibility to the HSV-2 pathology in vivo (165). The mediator of this effect was vaginal dysbiosis, which promoted IL-33 and impaired recruitment of memory T cells and reduced IFN- $\gamma$ production in the FRT. These mice also demonstrated marked eosinophil accumulation and elevated IL5 in the FRT (165). Furthermore, administration of recombinant IL-33 or protease-mediated induction of IL-33 in the vagina resulted in heightened susceptibility to HSV-2 (165). Oh et al. (166) elaborated on this model of IL-33-mediated type 2 immune 


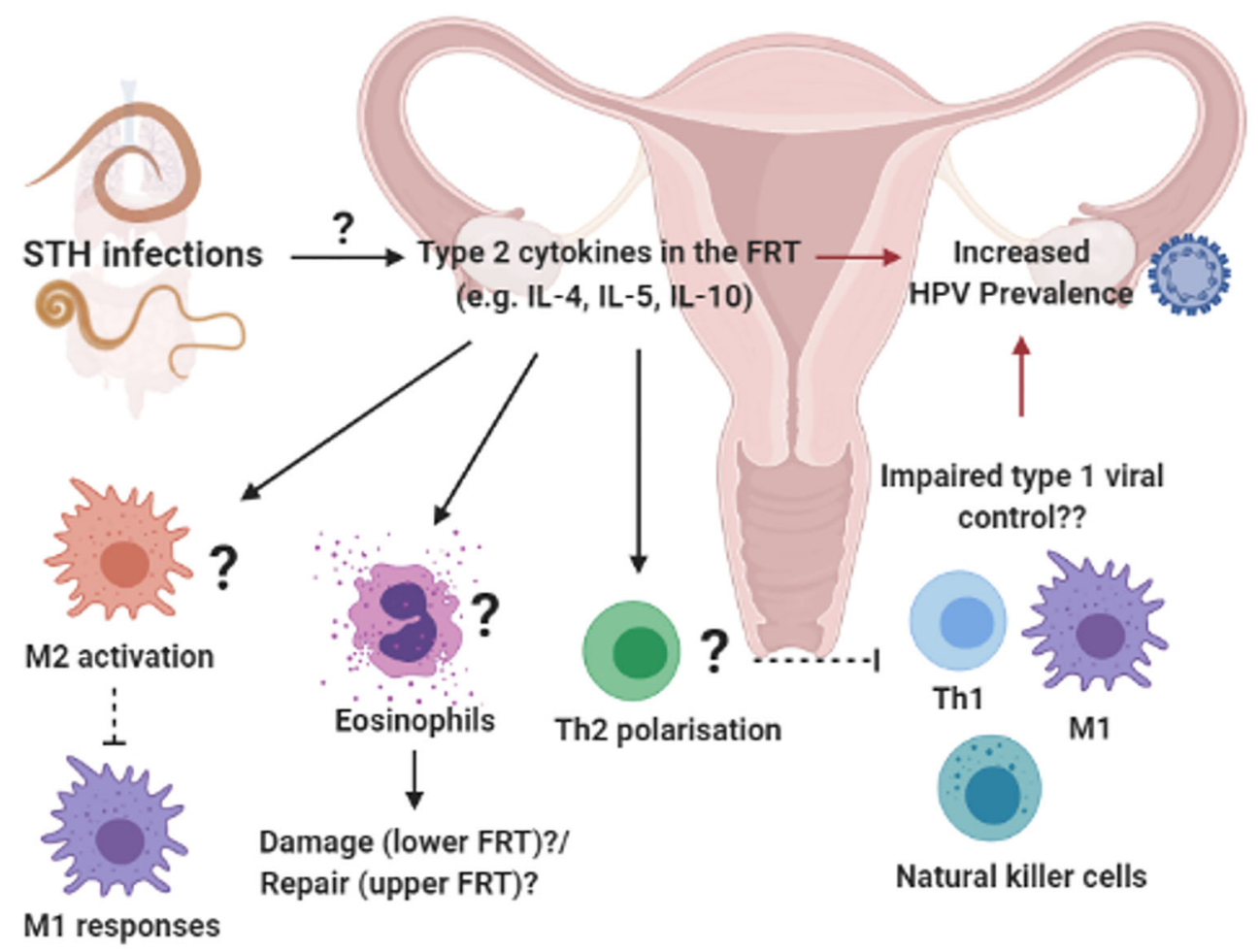

FIGURE 3 | Systemic influences of soil-transmitted helminths on uncolonized female reproductive tract (FRT): Prevalent soil-transmitted helminth (STH) infections, which transit the lung and GIT, can systemically alter host immunity in biological compartments not directly colonized by the parasite. For example, STH exposure was associated with increased HPV risk and a helminth-associated type 2 cytokine profile in vagina fluid of women in a STH endemic region (87). We hypothesize that the induction of type 2 immunity in the FRT e.g. type 2 cytokines activating M2 macrophages, eosinophils an Th2 differentiation of CD4 ${ }^{+} \mathrm{T}$ cells, could impair protective type 1 immune responses and increased susceptibility to viral STIs (52, 147-151). Created with BioRender.com.

induction in the FRT, through administration of the serine protease papain. Here, papain-induced IL-33 in the vagina lead to the accumulation of vaginal eosinophils and production of canonical type 2 cytokines IL-4, IL-5, and IL-13 in genital lymph node $\mathrm{T}$ cells (166). Furthermore, elevated levels of type 2associated IgE and IgG1 were detected in vaginal washes of papain-treated mice. Although elevated levels of IL-5 and eosinophils were detected in the FRT, papain induction of type 2 immunity in the FRT was not dependent on eosinophil recruitment, but rather on myeloid differentiation primary response gene $\underline{88}$ (MyD88) signaling and $\mathrm{PDL}_{2}{ }^{+} \mathrm{CD} 301 \mathrm{~b}^{+}$ dendritic cells under the control of interferon regulatory factor 4 (IRF4) (166).

Conversely, Vicetti Miguel et al. (151) demonstrated the protective role of type 2 immunity during in vivo $C$. trachomatis infection. Chlamydia-induced damage of the upper genital tract was prevented by IL-4 producing eosinophils, which promotes proliferation of endometrial stromal cells and tissue repair (151). Together, these studies demonstrate the significance of type 2 immunity in the FRT during STI infections and highlight potential differences in the role of type 2 responses at different sites in the FRT.

\section{Helminths and Fecundity}

The dichotomy of type 1: type 2 immune responses has been studied during the stages of pregnancy and labor, with a type 2 bias contributing to immune tolerance and a successful pregnancy (167). This would suggest that type 2-inducing helminth infections may systemically influence pregnancy in infected mothers in a positive manner. Interestingly, in vivo studies have demonstrated that helminth infection can result in pregnancy loss and failure of implantation of fertilized eggs (168), as well as reduced fecundity in parasitized hosts (169). Using a Schistosoma mansoni mouse model, Straubinger et al. (68) demonstrated that infected female mice gave birth to pups with lower birth weights during the Th2 phase of the immune response, as opposed to uninfected mice (68). In humans, Kurtis et al. (170) reported an association between maternal schistosomiasis and increased levels of inflammatory cytokines in mothers', placental and cord blood (170). As mother-to-child transmission of the schistosomes has not been reported in humans, the authors hypothesized the inflammatory response is likely due to helminth antigen movement across the placenta (170, 171). Furthermore, McDonald et al. (171) measured increased levels of pro-fibrotic proteins in the cord blood of 
neonates born to S. japonicum-infected mothers (171). Clinical trials by Ndibazza et al. (172) and Olveda et al. (173) reported that treatment of pregnant women in endemic regions with antiSchistosome drug praziquantel, did not significantly alter birth outcomes (172-174).

For maternal STH infections, Blackwell et al. (175) reported an association between hookworm infection and delayed age of first pregnancy and lower odds of successive pregnancies after the initial pregnancy. The converse was observed with Ascaris infection, which positively associated with conception at a younger age and shortened intervals of subsequent pregnancies after the first, among women younger than 32 years of age living in helminth endemic regions (175). The authors hypothesized that the opposing observations in fecundity between hookworm and Ascaris infections, is associated with the differing immune responses to the parasites; $A$. lumbricoides is associated with a polarized Th2 response (37) whereas hookworm infections may induce a mixed Th1/Th2 response (176). Together these studies suggest that helminth infections can have profound effects on female reproductive health, experimental investigation is required to better understanding of these effects.

\section{CONCLUDING REMARKS}

In this review, we have outlined the local and potential systemic effects of helminth infections on female reproductive health and

\section{REFERENCES}

1. de Silva NR, Brooker S, Hotez PJ, Montresor A, Engels D, Savioli L. Soiltransmitted helminth infections: updating the global picture. Trends Parasitol (2003) 19(12):547-51. doi: 10.1016/j.pt.2003.10.002

2. McSorley HJ, O'Gorman MT, Blair N, Sutherland TE, Filbey KJ, Maizels RM. Suppression of type 2 immunity and allergic airway inflammation by secreted products of the helminth Heligmosomoides polygyrus. Eur J Immunol (2012) 42(10):2667-82. doi: 10.1002/eji.201142161

3. du Plessis N, Kleynhans L, Thiart L, van Helden PD, Brombacher F, Horsnell WG, et al. Acute helminth infection enhances early macrophage mediated control of mycobacterial infection. Mucosal Immunol (2013) 6 (5):931-41. doi: 10.1038/mi.2012.131

4. Bobat S, Darby M, Mrdjen D, Cook C, Logan E, Auret J, et al. Natural and vaccine-mediated immunity to Salmonella Typhimurium is impaired by the helminth Nippostrongylus brasiliensis. PLoS Negl Trop Dis (2014) 8(12): e3341. doi: 10.1371/journal.pntd.0003341

5. Jõgi NO, Svanes C, Siiak SP, Logan E, Holloway JW, Igland J, et al. Zoonotic helminth exposure and risk of allergic diseases: A study of two generations in Norway. Clin Exp Allergy (2018) 48(1):66-77. doi: 10.1111/cea.13055

6. O’Shea MK, Fletcher TE, Muller J, Tanner R, Matsumiya M, Bailey JW, et al. Human Hookworm Infection Enhances Mycobacterial Growth Inhibition and Associates With Reduced Risk of Tuberculosis Infection. Front Immunol (2018) 9:2893. doi: 10.3389/fimmu.2018.02893

7. Rolot M, Dougall AM, Chetty A, Javaux J, Chen T, Xiao X, et al. Helminthinduced IL-4 expands bystander memory CD8(+) T cells for early control of viral infection. Nat Commun (2018) 9(1):4516. doi: 10.1038/s41467-01806978-5

8. Organizations WH. Sexually transmitted infections: implementing the Global STI Strategy: Evidence-to-action brief. WHO reference number: WHO/RHR/ 17.18. Geneva, Switzerland: World Health Organization (2017).

9. Ivan E, Crowther NJ, Rucogoza AT, Osuwat LO, Munyazesa E, Mutimura E, et al. Malaria and helminthic co-infection among HIV-positive pregnant susceptibility to STIs. Considering the great geographical overlap between STI and helminth prevalence, as well as the reduced access to health care and poor female health in helminth endemic regions, the study of helminth influences on the FRT should be a priority going forward, with focus on systemic effects of these parasites on uncolonized mucosal sites. Importantly, further comprehension on the systemic effects of GI helminths is needed, to direct health care strategies to mitigate the burden of helminth infections on the female reproductive health in those most at risk.

\section{AUTHOR CONTRIBUTION}

All authors contributed to the article and approved the submitted version.

\section{ACKNOWLEDGMENTS}

This study was supported by German Research Foundation (DFG) within the "German-Africa Cooperation Projects in Infectiology” (Grant LA 2746/2); CNRS of Orléans (France) and European funding in Region Centre-Val de Loire (FEDER $\mathrm{N}^{\circ}$ 2016-00110366 BIO-TARGET 322 and EX005756 BIOTARGET II); and the Poliomyelitis Research Foundation (PRF; 17/08).

women: prevalence and effects of antiretroviral therapy. Acta Trop (2012) 124(3):179-84. doi: 10.1016/j.actatropica.2012.08.004

10. Mkhize-Kwitshana ZL, Taylor M, Jooste P, Mabaso MLH, Walzl G. The influence of different helminth infection phenotypes on immune responses against HIV in co-infected adults in South Africa. BMC Infect Dis (2011) 11 (1):273. doi: 10.1186/1471-2334-11-273

11. Abossie A, Petros B. Deworming and the immune status of HIV positive preantiretroviral therapy individuals in Arba Minch, Chencha and Gidole hospitals, Southern Ethiopia. BMC Res Notes (2015) 8:483. doi: 10.1186/ s13104-015-1461-9

12. Gopinath R, Ostrowski M, Justement SJ, Fauci AS, Nutman TB. Filarial infections increase susceptibility to human immunodeficiency virus infection in peripheral blood mononuclear cells in vitro. J Infect Dis (2000) 182(6):1804-8. doi: 10.1086/317623

13. Wolday D, Mayaan S, Mariam ZG, Berhe N, Seboxa T, Britton S, et al. Treatment of intestinal worms is associated with decreased HIV plasma viral load. J Acquired Immune Defic Syndromes (1999) (2002) 31(1):56-62. doi: 10.1097/00126334-200209010-00008

14. Brown M, Mawa PA, Joseph S, Bukusuba J, Watera C, Whitworth JA, et al. Treatment of Schistosoma mansoni infection increases helminth-specific type 2 cytokine responses and HIV-1 loads in coinfected Ugandan adults. J Infect Dis (2005) 191(10):1648-57. doi: 10.1086/429668

15. Camberis M, Le Gros G, Urban JJr. Animal model of Nippostrongylus brasiliensis and Heligmosomoides polygyrus. Curr Protoc Immunol (2003) Chapter 19:Unit 19.2. doi: 10.1002/0471142735.im1912s55

16. Lawrence RA, Devaney E. Lymphatic filariasis: parallels between the immunology of infection in humans and mice. Parasit Immunol (2001) 23 (7):353-61. doi: 10.1046/j.1365-3024.2001.00396.x

17. Cliffe LJ, Grencis RK. The Trichuris muris system: a paradigm of resistance and susceptibility to intestinal nematode infection. Adv Parasitol (2004) 57:255-307. doi: 10.1016/S0065-308X(04)57004-5

18. Lewis R, Behnke JM, Stafford P, Holland CV. The development of a mouse model to explore resistance and susceptibility to early Ascaris suum 
infection. Parasitology (2006) 132(Pt 2):289-300. doi: 10.1017/ S0031182005008978

19. Shea-Donohue T, Sullivan C, Finkelman FD, Madden KB, Morris SC, Goldhill J, et al. The role of IL-4 in Heligmosomoides polygyrus-induced alterations in murine intestinal epithelial cell function. J Immunol (Baltimore Md: 1950) (2001) 167(4):2234-9. doi: 10.4049/jimmunol.167.4.2234

20. Madden KB, Whitman L, Sullivan C, Gause WC, Urban JFJr., Katona IM, et al. Role of STAT6 and mast cells in IL-4- and IL-13-induced alterations in murine intestinal epithelial cell function. J Immunol (Baltimore Md: 1950) (2002) 169(8):4417-22. doi: 10.4049/jimmunol.169.8.4417

21. Horsnell WG, Cutler AJ, Hoving JC, Mearns H, Myburgh E, Arendse B, et al. Delayed goblet cell hyperplasia, acetylcholine receptor expression, and worm expulsion in SMC-specific IL-4Ralpha-deficient mice. PLoS Pathog (2007) 3 (1):e1. doi: 10.1371/journal.ppat.0030001

22. Mearns H, Horsnell WG, Hoving JC, Dewals B, Cutler AJ, Kirstein F, et al. Interleukin-4-promoted $\mathrm{T}$ helper 2 responses enhance Nippostrongylus brasiliensis-induced pulmonary pathology. Infect Immun (2008) 76 (12):5535-42. doi: 10.1128/IAI.00210-08

23. Horsnell WGC, Vira A, Kirstein F, Mearns H, Hoving JC, Cutler AJ, et al. IL$4 \mathrm{R} \alpha$-responsive smooth muscle cells contribute to initiation of TH2 immunity and pulmonary pathology in Nippostrongylus brasiliensis infections. Mucosal Immunol (2010) 4:83. doi: 10.1038/mi.2010.46

24. Schmidt S, Hoving JC, Horsnell WGC, Mearns H, Cutler AJ, Brombacher TM, et al. Nippostrongylus-Induced Intestinal Hypercontractility Requires IL-4 Receptor Alpha-Responsiveness by T Cells in Mice. PLoS One (2012) 7 (12):e52211. doi: 10.1371/journal.pone.0052211

25. Thawer SG, Horsnell WG, Darby M, Hoving JC, Dewals B, Cutler AJ, et al. Lung-resident $\mathrm{CD} 4+\mathrm{T}$ cells are sufficient for IL-4R $\alpha$-dependent recall immunity to Nippostrongylus brasiliensis infection. Mucosal Immunol (2013) 7:239. doi: 10.1038/mi.2013.40

26. Finkelman FD, Shea-Donohue T, Morris SC, Gildea L, Strait R, Madden KB, et al. Interleukin-4- and interleukin-13-mediated host protection against intestinal nematode parasites. Immunol Rev (2004) 201:139-55. doi: 10.1111/j.0105-2896.2004.00192.x

27. Neill DR, Wong SH, Bellosi A, Flynn RJ, Daly M, Langford TK, et al. Nuocytes represent a new innate effector leukocyte that mediates type-2 immunity. Nature (2010) 464(7293):1367-70. doi: 10.1038/nature08900

28. Klose CS, Artis D. Innate lymphoid cells as regulators of immunity, inflammation and tissue homeostasis. Nat Immunol (2016) 17(7):765-74. doi: 10.1038/ni.3489

29. Nussbaum JC, Van Dyken SJ, von Moltke J, Cheng LE, Mohapatra A, Molofsky $\mathrm{AB}$, et al. Type 2 innate lymphoid cells control eosinophil homeostasis. Nature (2013) 502(7470):245-8. doi: 10.1038/nature12526

30. Patnode ML, Bando JK, Krummel MF, Locksley RM, Rosen SD. Leukotriene B4 amplifies eosinophil accumulation in response to nematodes. J Exp Med (2014) 211(7):1281-8. doi: 10.1084/jem.20132336

31. Knott ML, Matthaei KI, Foster PS, Dent LA. The roles of eotaxin and the STAT6 signalling pathway in eosinophil recruitment and host resistance to the nematodes Nippostrongylus brasiliensis and Heligmosomoides bakeri. Mol Immunol (2009) 46(13):2714-22. doi: 10.1016/j.molimm.2009.05.016

32. Ganley-Leal LM, Mwinzi PN, Cetre-Sossah CB, Andove J, Hightower AW, Karanja DM, et al. Correlation between eosinophils and protection against reinfection with Schistosoma mansoni and the effect of human immunodeficiency virus type 1 coinfection in humans. Infect Immun (2006) 74(4):2169-76. doi: 10.1128/IAI.74.4.2169-2176.2006

33. Zhao A, McDermott J, Urban JF, Gause W, Madden KB, Yeung KA, et al. Dependence of IL-4, IL-13, and Nematode-Induced Alterations in Murine Small Intestinal Smooth Muscle Contractility on Stat6 and Enteric Nerves. J Immunol (2003) 171(2):948-54. doi: 10.4049/jimmunol.171.2.948

34. Zhao A, Urban JFJr., Anthony RM, Sun R, Stiltz J, van Rooijen N, et al. Th2 cytokine-induced alterations in intestinal smooth muscle function depend on alternatively activated macrophages. Gastroenterology (2008) 135(1):21725.e1. doi: 10.1053/j.gastro.2008.03.077

35. Turner JD, Faulkner H, Kamgno J, Cormont F, Van Snick J, Else KJ, et al. Th2 cytokines are associated with reduced worm burdens in a human intestinal helminth infection. J Infect Dis (2003) 188(11):1768-75. doi: 10.1086/379370

36. Jackson JA, Turner JD, Rentoul L, Faulkner H, Behnke JM, Hoyle M, et al. Cytokine response profiles predict species-specific infection patterns in human GI nematodes. Int J Parasitol (2004) 34(11):1237-44. doi: 10.1016/ j.ijpara.2004.07.009

37. Geiger SM, Massara CL, Bethony J, Soboslay PT, Carvalho OS, CorrêaOliveira R. Cellular responses and cytokine profiles in Ascaris lumbricoides and Trichuris trichiura infected patients. Parasit Immunol (2002) 24(1112):499-509. doi: 10.1046/j.1365-3024.2002.00600.x

38. Jackson JA, Turner JD, Rentoul L, Faulkner H, Behnke JM, Hoyle M, et al. T helper cell type 2 responsiveness predicts future susceptibility to gastrointestinal nematodes in humans. J Infect Dis (2004) 190(10):180411. doi: $10.1086 / 425014$

39. Quinnell RJ, Pritchard DI, Raiko A, Brown AP, Shaw MA. Immune responses in human necatoriasis: association between interleukin-5 responses and resistance to reinfection. J Infect Dis (2004) 190(3):430-8. doi: $10.1086 / 422256$

40. Gaze S, McSorley HJ, Daveson J, Jones D, Bethony JM, Oliveira LM, et al. Characterising the mucosal and systemic immune responses to experimental human hookworm infection. PLoS Pathog (2012) 8(2):e1002520-e. doi: 10.1371/journal.ppat. 1002520

41. Grainger JR, Smith KA, Hewitson JP, McSorley HJ, Harcus Y, Filbey KJ, et al. Helminth secretions induce de novo $\mathrm{T}$ cell Foxp 3 expression and regulatory function through the TGF-beta pathway. J Exp Med (2010) 207(11):2331-41. doi: 10.1084/jem.20101074

42. Johnston CJC, Smyth DJ, Kodali RB, White MPJ, Harcus Y, Filbey KJ, et al. A structurally distinct TGF- $\beta$ mimic from an intestinal helminth parasite potently induces regulatory T cells. Nat Commun (2017) 8(1):1741. doi: 10.1038/s41467-017-01886-6

43. Maizels RM, Smits HH, McSorley HJ. Modulation of Host Immunity by Helminths: The Expanding Repertoire of Parasite Effector Molecules. Immunity (2018) 49(5):801-18. doi: 10.1016/j.immuni.2018.10.016

44. McSorley HJ, Harcus YM, Murray J, Taylor MD, Maizels RM. Expansion of Foxp3+ regulatory $\mathrm{T}$ cells in mice infected with the filarial parasite Brugia malayi. J Immunol (Baltimore Md: 1950) (2008) 181(9):6456-66. doi 10.4049/jimmunol.181.9.6456

45. Watanabe K, Mwinzi PN, Black CL, Muok EM, Karanja DM, Secor WE, et al. T regulatory cell levels decrease in people infected with Schistosoma mansoni on effective treatment. Am J Trop Med Hyg (2007) 77(4):676-82. doi: 10.4269/ajtmh.2007.77.676

46. Doetze A, Satoguina J, Burchard G, Rau T, Loliger C, Fleischer B, et al. Antigen-specific cellular hyporesponsiveness in a chronic human helminth infection is mediated by $\mathrm{T}(\mathrm{h}) 3 / \mathrm{T}(\mathrm{r}) 1$-type cytokines IL-10 and transforming growth factor-beta but not by a T(h)1 to T(h)2 shift. Int Immunol (2000) 12 (5):623-30. doi: 10.1093/intimm/12.5.623

47. Satoguina J, Mempel M, Larbi J, Badusche M, Löliger C, Adjei O, et al. Antigen-specific T regulatory-1 cells are associated with immunosuppression in a chronic helminth infection (onchocerciasis). Microbes Infect (2002) 4 (13):1291-300. doi: 10.1016/S1286-4579(02)00014-X

48. Ricci ND, Fiúza JA, Bueno LL, Cançado GG, Gazzinelli-Guimarães PH, Martins VG, et al. Induction of CD4(+)CD25(+)FOXP3(+) regulatory T cells during human hookworm infection modulates antigen-mediated lymphocyte proliferation. PLoS Negl Trop Dis (2011) 5(11):e1383. doi: 10.1371/journal.pntd.0001383

49. Mosmann TR, Cherwinski H, Bond MW, Giedlin MA, Coffman RL. Two types of murine helper T cell clone. I. Definition according to profiles of lymphokine activities and secreted proteins. J Immunol (Baltimore $\mathrm{Md}$ : 1950) (1986) 136(7):2348-57.

50. Mosmann TR, Coffman RL. TH1 and TH2 cells: different patterns of lymphokine secretion lead to different functional properties. Annu Rev Immunol (1989) 7:145-73. doi: 10.1146/annurev.iy.07.040189.001045

51. Fernandez-Botran R, Sanders VM, Mosmann TR, Vitetta ES. Lymphokinemediated regulation of the proliferative response of clones of $\mathrm{T}$ helper 1 and T helper 2 cells. J Exp Med (1988) 168(2):543-58. doi: 10.1084/ jem.168.2.543

52. Reese TA, Wakeman BS, Choi HS, Hufford MM, Huang SC, Zhang X, et al. Helminth infection reactivates latent -herpesvirus via cytokine competition at a viral promoter. Science (2014) 345(6196):573-7. doi: 10.1126/ science. 1254517

53. Briken V, Mosser DM. Editorial: switching on arginase in M2 macrophages. J Leukoc Biol (2011) 90(5):839-41. doi: 10.1189/jlb.0411203 
54. Taylor MD, Harris A, Nair MG, Maizels RM, Allen JE. F4/80+ alternatively activated macrophages control CD4+ $\mathrm{T}$ cell hyporesponsiveness at sites peripheral to filarial infection. J Immunol (Baltimore Md: 1950 (2006) 176 (11):6918-27. doi: 10.4049/jimmunol.176.11.6918

55. Smith KA, Filbey KJ, Reynolds LA, Hewitson JP, Harcus Y, Boon L, et al. Low-level regulatory T-cell activity is essential for functional type-2 effector immunity to expel gastrointestinal helminths. Mucosal Immunol (2016) 9 (2):428-43. doi: 10.1038/mi.2015.73

56. Finney CA, Taylor MD, Wilson MS, Maizels RM. Expansion and activation of $\mathrm{CD} 4(+) \mathrm{CD} 25(+)$ regulatory $\mathrm{T}$ cells in Heligmosomoides polygyrus infection. Eur J Immunol (2007) 37(7):1874-86. doi: 10.1002/eji.200636751

57. Bancroft AJ, Levy CW, Jowitt TA, Hayes KS, Thompson S, McKenzie EA, et al. The major secreted protein of the whipworm parasite tethers to matrix and inhibits interleukin-13 function. Nat Commun (2019) 10(1):2344-. doi: 10.1038/s41467-019-09996-z

58. Ritter M, Osei-Mensah J, Debrah LB, Kwarteng A, Mubarik Y, Debrah AY, et al. Wuchereria bancrofti-infected individuals harbor distinct IL-10producing regulatory $\mathrm{B}$ and $\mathrm{T}$ cell subsets which are affected by antifilarial treatment. PLoS Negl Trop Dis (2019) 13(5):e0007436. doi: 10.1371/ journal.pntd.0007436

59. Sartono E, Kruize YC, Kurniawan A, van der Meide PH, Partono F, Maizels $\mathrm{RM}$, et al. Elevated cellular immune responses and interferon-gamma release after long-term diethylcarbamazine treatment of patients with human lymphatic filariasis. J Infect Dis (1995) 171(6):1683-7. doi: 10.1093/infdis/ 171.6 .1683

60. Mahanty S, Mollis SN, Ravichandran M, Abrams JS, Kumaraswami V, Jayaraman $\mathrm{K}$, et al. High levels of spontaneous and parasite antigen-driven interleukin-10 production are associated with antigen-specific hyporesponsiveness in human lymphatic filariasis. J Infect Dis (1996) 173 (3):769-73. doi: 10.1093/infdis/173.3.769

61. King CL, Mahanty S, Kumaraswami V, Abrams JS, Regunathan J, Jayaraman K, et al. Cytokine control of parasite-specific anergy in human lymphatic filariasis. Preferential induction of a regulatory T helper type 2 lymphocyte subset. J Clin Invest (1993) 92(4):1667-73. doi: 10.1172/JCI116752

62. Babu S, Bhat SQ, Kumar NP, Jayantasri S, Rukmani S, Kumaran P, et al. Human type 1 and 17 responses in latent tuberculosis are modulated by coincident filarial infection through cytotoxic $\mathrm{T}$ lymphocyte antigen-4 and programmed death-1. J Infect Dis (2009) 200(2):288-98. doi: 10.1086/ 599797

63. Katawa G, Layland LE, Debrah AY, von Horn C, Batsa L, Kwarteng A, et al. Hyperreactive onchocerciasis is characterized by a combination of Th17Th2 immune responses and reduced regulatory T cells. PLoS Negl Trop Dis (2015) 9(1):e3414. doi: 10.1371/journal.pntd.0003414

64. Li Y, Guan X, Liu W, Chen H-L, Truscott J, Beyatli S, et al. HelminthInduced Production of TGF- $\beta$ and Suppression of Graft-versus-Host Disease Is Dependent on IL-4 Production by Host Cells. J Immunol (2018) 201(10):2910-22. doi: 10.4049/jimmunol.1700638

65. Ferreira IB, Pickering DA, Troy S, Croese J, Loukas A, Navarro S. Suppression of inflammation and tissue damage by a hookworm recombinant protein in experimental colitis. Clin Trans Immunol (2017) 6 (10):e157. doi: 10.1038/cti.2017.42

66. Navarro S, Pickering DA, Ferreira IB, Jones L, Ryan S, Troy S, et al. Hookworm recombinant protein promotes regulatory $\mathrm{T}$ cell responses that suppress experimental asthma. Sci Trans Med (2016) 8 (362):362ra143-362ra143. doi: 10.1126/scitranslmed.aaf8807

67. Layland LE, Straubinger K, Ritter M, Loffredo-Verde E, Garn H, Sparwasser T, et al. Schistosoma mansoni-Mediated Suppression of Allergic Airway Inflammation Requires Patency and Foxp3+ Treg Cells. PLoS Negl Trop Dis (2013) 7(8):e2379. doi: 10.1371/journal.pntd.0002379

68. Straubinger K, Paul S, Prazeres da Costa O, Ritter M, Buch T, Busch DH, et al. Maternal immune response to helminth infection during pregnancy determines offspring susceptibility to allergic airway inflammation. J Allergy Clin Immunol (2014) 134(6):1271-9.e10. doi: 10.1016/j.jaci.2014.05.034

69. Osbourn M, Soares DC, Vacca F, Cohen ES, Scott IC, Gregory WF, et al. HpARI Protein Secreted by a Helminth Parasite Suppresses Interleukin-33. Immunity (2017) 47(4):739-51.e5. doi: 10.1016/j.immuni.2017.09.015

70. Zaiss Mario M, Rapin A, Lebon L, Dubey Lalit K, Mosconi I, Sarter K, et al. The Intestinal Microbiota Contributes to the Ability of Helminths to
Modulate Allergic Inflammation. Immunity (2015) 43(5):998-1010. doi: 10.1016/j.immuni.2015.09.012

71. Pinelli E, Brandes S, Dormans J, Gremmer E, van Loveren H. Infection with the roundworm Toxocara canis leads to exacerbation of experimental allergic airway inflammation. Clin Exp Allergy (2008) 38(4):649-58. doi: 10.1111/j.1365-2222.2007.02908.x

72. Darby MG, Chetty A, Mrjden D, Rolot M, Smith K, Mackowiak C, et al. Preconception maternal helminth infection transfers via nursing long-lasting cellular immunity against helminths to offspring. Sci $A d v$ (2019) 5(5): eav3058. doi: 10.1126/sciadv.aav3058

73. Sabin EA, Araujo MI, Carvalho EM, Pearce EJ. Impairment of tetanus toxoid-specific Th1-like immune responses in humans infected with Schistosoma mansoni. J Infect Dis (1996) 173(1):269-72. doi: 10.1093/ infdis/173.1.269

74. Cooper PJ, Chico M, Sandoval C, Espinel I, Guevara A, Levine MM, et al. Human infection with Ascaris lumbricoides is associated with suppression of the interleukin-2 response to recombinant cholera toxin B subunit following vaccination with the live oral cholera vaccine CVD 103-HgR. Infect Immun (2001) 69(3):1574-80. doi: 10.1128/IAI.69.3.1574-1580.2001

75. Elias D, Wolday D, Akuffo H, Petros B, Bronner U, Britton S. Effect of deworming on human $\mathrm{T}$ cell responses to mycobacterial antigens in helminth-exposed individuals before and after bacille Calmette-Guerin (BCG) vaccination. Clin Exp Immunol (2001) 123(2):219-25. doi: 10.1046/ j.1365-2249.2001.01446.x

76. Nookala S, Srinivasan S, Kaliraj P, Narayanan RB, Nutman TB. Impairment of tetanus-specific cellular and humoral responses following tetanus vaccination in human lymphatic filariasis. Infect Immun (2004) 72 (5):2598-604. doi: 10.1128/IAI.72.5.2598-2604.2004

77. Apiwattanakul N, Thomas PG, Iverson AR, McCullers JA. Chronic helminth infections impair pneumococcal vaccine responses. Vaccine (2014) 32 (42):5405-10. doi: 10.1016/j.vaccine.2014.07.107

78. Osborne LC, Monticelli LA, Nice TJ, Sutherland TE, Siracusa MC, Hepworth $\mathrm{MR}$, et al. Virus-helminth coinfection reveals a microbiota-independent mechanism of immunomodulation. Science (2014) 345(6196):578-82. doi: $10.1126 /$ science. 1256942

79. McFarlane AJ, McSorley HJ, Davidson DJ, Fitch PM, Errington C, Mackenzie KJ, et al. Enteric helminth-induced type I interferon signaling protects against pulmonary virus infection through interaction with the microbiota. J Allergy Clin Immunol (2017) 140(4):1068-78.e6. doi: 10.1016/ j.jaci.2017.01.016

80. Furze RC, Hussell T, Selkirk ME. Amelioration of Influenza-Induced Pathology in Mice by Coinfection with Trichinella spiralis. Infect Immun (2006) 74(3):1924-32. doi: 10.1128/IAI.74.3.1924-1932.2006

81. Metenou S, Babu S, Nutman TB. Impact of filarial infections on coincident intracellular pathogens: Mycobacterium tuberculosis and Plasmodium falciparum. Curr Opin HIV AIDS (2012) 7(3):231-8. doi: 10.1097/ COH.0b013e3283522c3d

82. Rajamanickam A, Munisankar S, Bhootra Y, Dolla CK, Nutman TB, Babu S. Coexistent Helminth Infection-Mediated Modulation of Chemokine Responses in Latent Tuberculosis. J Immunol (Baltimore Md: 1950) (2019) 202(5):1494-500. doi: 10.4049/jimmunol.1801190

83. Chard AN, Baker KK, Tsai K, Levy K, Sistrunk JR, Chang HH, et al. Associations between soil-transmitted helminthiasis and viral, bacterial, and protozoal enteroinfections: a cross-sectional study in rural Laos. Parasit Vectors (2019) 12(1):216. doi: 10.1186/s13071-019-3471-2

84. Yasuda K, Adachi T, Koida A, Nakanishi K. Nematode-Infected Mice Acquire Resistance to Subsequent Infection With Unrelated Nematode by Inducing Highly Responsive Group 2 Innate Lymphoid Cells in the Lung. Front Immunol (2018) 9:2132. doi: 10.3389/fimmu.2018.02132

85. Filbey KJ, Camberis M, Chandler J, Turner R, Kettle AJ, Eichenberger RM, et al. Intestinal helminth infection promotes IL-5- and CD4+ T celldependent immunity in the lung against migrating parasites. Mucosal Immunol (2019) 12(2):352-62. doi: 10.1038/s41385-018-0102-8

86. Price AE, Liang H-E, Sullivan BM, Reinhardt RL, Eisley CJ, Erle DJ, et al. Systemically dispersed innate IL-13-expressing cells in type 2 immunity. Proc Natl Acad Sci (2010) 107(25):11489-94. doi: 10.1073/pnas.1003988107

87. Gravitt PE, Marks M, Kosek M, Huang C, Cabrera L, Olortegui MP, et al. Soil-Transmitted Helminth Infections Are Associated With an Increase in 
Human Papillomavirus Prevalence and a T-Helper Type 2 Cytokine Signature in Cervical Fluids. J Infect Dis (2016) 213(5):723-30. doi: 10.1093/infdis/jiv498

88. Borgdorff H, Gautam R, Armstrong SD, Xia D, Ndayisaba GF, van Teijlingen $\mathrm{NH}$, et al. Cervicovaginal microbiome dysbiosis is associated with proteome changes related to alterations of the cervicovaginal mucosal barrier. Mucosal Immunol (2016) 9(3):621-33. doi: 10.1038/mi.2015.86

89. Wira CR, Fahey JV, Rodriguez-Garcia M, Shen Z, Patel MV. Regulation of mucosal immunity in the female reproductive tract: the role of sex hormones in immune protection against sexually transmitted pathogens. Am J Reprod Immunol (2014) 72(2):236-58. doi: 10.1111/aji.12252

90. Valore EV, Park CH, Igreti SL, Ganz T. Antimicrobial components of vaginal fluid. Am J Obstet Gynecol (2002) 187(3):561-8. doi: 10.1067/ mob.2002.125280

91. Kaushic C. HIV-1 Infection in the Female Reproductive Tract: Role of Interactions between HIV-1 and Genital Epithelial Cells. Am J Reprod Immunol (2011) 65(3):253-60. doi: 10.1111/j.1600-0897.2010.00965.x

92. Chan T, Barra NG, Lee AJ, Ashkar AA. Innate and adaptive immunity against herpes simplex virus type 2 in the genital mucosa. J Reprod Immunol (2011) 88(2):210-8. doi: 10.1016/j.jri.2011.01.001

93. Iwasaki A. Mucosal dendritic cells. Annu Rev Immunol (2007) 25:381-418. doi: 10.1146/annurev.immunol.25.022106.141634

94. Zhao X, Deak E, Soderberg K, Linehan M, Spezzano D, Zhu J, et al. Vaginal submucosal dendritic cells, but not Langerhans cells, induce protective Th1 responses to herpes simplex virus-2. J Exp Med (2003) 197(2):153-62. doi: 10.1084/jem.20021109

95. Perez-Zsolt D, Cantero-Pérez J, Erkizia I, Benet S, Pino M, Serra-Peinado C, et al. Dendritic Cells From the Cervical Mucosa Capture and Transfer HIV-1 via Siglec-1. Front Immunol (2019) 10(825). doi: 10.3389/fimmu.2019.00825

96. Spellberg B, Edwards JEJr. Type 1/Type 2 immunity in infectious diseases. Clin Infect Dis (2001) 32(1):76-102. doi: 10.1086/317537

97. Shin HD, Winkler C, Stephens JC, Bream J, Young H, Goedert JJ, et al. Genetic restriction of HIV-1 pathogenesis to AIDS by promoter alleles of IL10. Proc Natl Acad Sci U S A (2000) 97(26):14467-72. doi: 10.1073/ pnas.97.26.14467

98. McGuirk P, Mills KH. Pathogen-specific regulatory T cells provoke a shift in the Th1/Th2 paradigm in immunity to infectious diseases. Trends Immunol (2002) 23(9):450-5. doi: 10.1016/S1471-4906(02)02288-3

99. Bettahi I, Zhang X, Afifi RE, BenMohamed L. Protective immunity to genital herpes simplex virus type 1 and type 2 provided by self-adjuvanting lipopeptides that drive dendritic cell maturation and elicit a polarized $\mathrm{Th} 1$ immune response. Viral Immunol (2006) 19(2):220-36. doi: 10.1089/vim.2006.19.220

100. Scott M, Stites DP, Moscicki AB. Th1 cytokine patterns in cervical human papillomavirus infection. Clin Diagn Lab Immunol (1999) 6(5):751-5. doi: 10.1128/CDLI.6.5.751-755.1999

101. Maloy KJ, Burkhart C, Junt TM, Odermatt B, Oxenius A, Piali L, et al. CD4 (+) T cell subsets during virus infection. Protective capacity depends on effector cytokine secretion and on migratory capability. J Exp Med (2000) 191 (12):2159-70. doi: 10.1084/jem.191.12.2159

102. Goldszmid Romina S, Caspar P, Rivollier A, White S, Dzutsev A, Hieny S, et al. NK Cell-Derived Interferon- $\gamma$ Orchestrates Cellular Dynamics and the Differentiation of Monocytes into Dendritic Cells at the Site of Infection. Immunity (2012) 36(6):1047-59. doi: 10.1016/j.immuni.2012.03.026

103. Lee AJ, Chen B, Chew MV, Barra NG, Shenouda MM, Nham T, et al. Inflammatory monocytes require type I interferon receptor signaling to activate NK cells via IL-18 during a mucosal viral infection. J Exp Med (2017) 214(4):1153-67. doi: 10.1084/jem.20160880

104. Butz EA, Bevan MJ. Massive expansion of antigen-specific CD8+ T cells during an acute virus infection. Immunity (1998) 8(2):167-75. doi: 10.1016/ S1074-7613(00)80469-0

105. Dobbs ME, Strasser JE, Chu CF, Chalk C, Milligan GN. Clearance of herpes simplex virus type 2 by $\mathrm{CD} 8+\mathrm{T}$ cells requires gamma interferon and either perforin- or Fas-mediated cytolytic mechanisms. J Virol (2005) 79 (23):14546-54. doi: 10.1128/JVI.79.23.14546-14554.2005

106. Koelle DM, Posavad CM, Barnum GR, Johnson ML, Frank JM, Corey L. Clearance of HSV-2 from recurrent genital lesions correlates with infiltration of HSV-specific cytotoxic T lymphocytes. JClin Invest (1998) 101(7):1500-8. doi: 10.1172/JCI1758
107. Deng K, Pertea M, Rongvaux A, Wang L, Durand CM, Ghiaur G, et al. Broad CTL response is required to clear latent HIV-1 due to dominance of escape mutations. Nature (2015) 517(7534):381-5. doi: 10.1038/nature14053

108. Murthy AK, Li W, Chaganty BKR, Kamalakaran S, Guentzel MN, Seshu J, et al. Tumor necrosis factor alpha production from $\mathrm{CD} 8+\mathrm{T}$ cells mediates oviduct pathological sequelae following primary genital Chlamydia muridarum infection. Infect Immun (2011) 79(7):2928-35. doi: 10.1128/ IAI.05022-11

109. Jordan SJ, Gupta K, Ogendi BMO, Bakshi RK, Kapil R, Press CG, et al. The Predominant $\mathrm{CD} 4(+)$ Th1 Cytokine Elicited to Chlamydia trachomatis Infection in Women Is Tumor Necrosis Factor Alpha and Not Interferon Gamma. Clin Vaccine Immunol (2017) 24(4):e00010-17. doi: 10.1128/ CVI.00010-17

110. Borrow P, Lewicki H, Hahn BH, Shaw GM, Oldstone MB. Virus-specific CD8+ cytotoxic T-lymphocyte activity associated with control of viremia in primary human immunodeficiency virus type 1 infection. J Virol (1994) 68 (9):6103-10. doi: 10.1128/JVI.68.9.6103-6110.1994

111. Masson L, Passmore J-AS, Liebenberg LJ, Werner L, Baxter C, Arnold KB, et al. Genital inflammation and the risk of HIV acquisition in women. Clin Infect Dis (2015) 61(2):260-9. doi: 10.1093/cid/civ298

112. Ganatra SR, Bucsan AN, Alvarez X, Kumar S, Chatterjee A, Quezada M, et al. Anti-retroviral therapy does not reduce tuberculosis reactivation in a tuberculosis-HIV co-infection model. J Clin Invest (2020) 130(10):5171-9. doi: $10.1172 /$ JCI136502

113. Borges ÁH. Combination antiretroviral therapy and cancer risk. Curr Opin HIV AIDS (2017) 12(1):12-9. doi: 10.1097/COH.0000000000000334

114. Feinen B, Jerse AE, Gaffen SL, Russell MW. Critical role of Th17 responses in a murine model of Neisseria gonorrhoeae genital infection. Mucosal Immunol (2010) 3(3):312-21. doi: 10.1038/mi.2009.139

115. Vasilevsky S, Greub G, Nardelli-Haefliger D, Baud D. Genital Chlamydia trachomatis: understanding the roles of innate and adaptive immunity in vaccine research. Clin Microbiol Rev (2014) 27(2):346-70. doi: 10.1128/ CMR.00105-13

116. WHO Guidelines Approved by the Guidelines Review Committee. WHO Guidelines for the Treatment of Chlamydia trachomatis. Geneva: World Health Organization Copyright () World Health Organization 2016 (2016).

117. Poston TB, Darville T. Chlamydia trachomatis: Protective Adaptive Responses and Prospects for a Vaccine. Curr Topics Microbiol Immunol (2018) 412:217-37. doi: 10.1007/82_2016_6

118. Vicetti Miguel RD, Quispe Calla NE, Pavelko SD, Cherpes TL. Intravaginal Chlamydia trachomatis Challenge Infection Elicits TH1 and TH17 Immune Responses in Mice That Promote Pathogen Clearance and Genital Tract Damage. PLoS One (2016) 11(9):e0162445-e. doi: 10.1371/journal.pone. 0162445

119. Kanhere A, Hertweck A, Bhatia U, Gökmen MR, Perucha E, Jackson I, et al. T-bet and GATA 3 orchestrate Th1 and Th2 differentiation through lineagespecific targeting of distal regulatory elements. Nat Commun (2012) 3 (1):1268. doi: 10.1038/ncomms 2260

120. Zhou L, Lopes JE, Chong MM, Ivanov II, Min R, Victora GD, et al. TGFbeta-induced Foxp3 inhibits $\mathrm{T}(\mathrm{H}) 17$ cell differentiation by antagonizing RORgammat function. Nature (2008) 453(7192):236-40. doi: 10.1038/ nature 06878

121. Odegaard JI, Hsieh MH. Immune responses to Schistosoma haematobium infection. Parasit Immunol (2014) 36(9):428-38. doi: 10.1111/pim.12084

122. Hegertun IEA, Sulheim Gundersen KM, Kleppa E, Zulu SG, Gundersen SG, Taylor M, et al. S. haematobium as a Common Cause of Genital Morbidity in Girls: A Cross-sectional Study of Children in South Africa. PLoS Negl Trop Dis (2013) 7(3):e2104. doi: 10.1371/journal. pntd.0002104

123. Norseth HM, Ndhlovu PD, Kleppa E, Randrianasolo BS, Jourdan PM, Roald B, et al. The Colposcopic Atlas of Schistosomiasis in the Lower Female Genital Tract Based on Studies in Malawi, Zimbabwe, Madagascar and South Africa. PLoS Negl Trop Dis (2014) 8(11):e3229. doi: 10.1371/journal.pntd. 0003229

124. Ismail HAHA, Hong S-T, Babiker ATEB, Hassan RMAE, Sulaiman MAZ, Jeong $\mathrm{H}-\mathrm{G}$, et al. Prevalence, risk factors, and clinical manifestations of schistosomiasis among school children in the White Nile River basin, Sudan. Parasit Vectors (2014) 7:478. doi: 10.1186/s13071-014-0478-6 
125. Randrianasolo BS, Jourdan PM, Ravoniarimbinina P, Ramarokoto CE, Rakotomanana F, Ravaoalimalala VE, et al. Gynecological manifestations, histopathological findings, and schistosoma-specific polymerase chain reaction results among women with Schistosoma haematobium infection: a cross-sectional study in Madagascar. J Infect Dis (2015) 212(2):275-84. doi: 10.1093/infdis/jiv035

126. Ishida $\mathrm{K}$, Hsieh $\mathrm{MH}$. Understanding Urogenital Schistosomiasis-Related Bladder Cancer: An Update. Front Med (2018) 5:223. doi: 10.3389/ fmed.2018.00223

127. Fu CL, Odegaard JI, Herbert DR, Hsieh MH. A novel mouse model of Schistosoma haematobium egg-induced immunopathology. PLoS Pathog (2012) 8(3):e1002605. doi: 10.1371/journal.ppat.1002605

128. Looker KJ, Elmes JAR, Gottlieb SL, Schiffer JT, Vickerman P, Turner KME, et al. Effect of HSV-2 infection on subsequent HIV acquisition: an updated systematic review and meta-analysis. Lancet Infect Dis (2017) 17(12):130316. doi: 10.1016/S1473-3099(17)30405-X

129. Wright ED, Chiphangwi J, Hutt MS. Schistosomiasis of the female genital tract. A histopathological study of 176 cases from Malawi. Trans R Soc Trop Med Hyg (1982) 76(6):822-9. doi: 10.1016/0035-9203(82)90118-3

130. Helling-Giese G, Sjaastad A, Poggensee G, Kjetland EF, Richter J, Chitsulo L, et al. Female genital schistosomiasis (FGS): relationship between gynecological and histopathological findings. Acta Trop (1996) 62(4):25767. doi: 10.1016/S0001-706X(96)00027-7

131. Nausch N, Midzi N, Mduluza T, Maizels RM, Mutapi F. Regulatory and activated $\mathrm{T}$ cells in human Schistosoma haematobium infections. PLoS One (2011) 6(2):e16860. doi: 10.1371/journal.pone.0016860

132. Klatt NR, Chomont N, Douek DC, Deeks SG. Immune activation and HIV persistence: implications for curative approaches to HIV infection. Immunol $\operatorname{Rev}(2013)$ 254(1):326-42. doi: 10.1111/imr.12065

133. Kjetland EF, Ndhlovu PD, Gomo E, Mduluza T, Midzi N, Gwanzura L, et al. Association between genital schistosomiasis and HIV in rural Zimbabwean women. AIDS (Lond Engl) (2006) 20(4):593-600. doi: 10.1097/ 01.aids.0000210614.45212.0a

134. Ndhlovu PD, Mduluza T, Kjetland EF, Midzi N, Nyanga L, Gundersen SG, et al. Prevalence of urinary schistosomiasis and HIV in females living in a rural community of Zimbabwe: does age matter? Trans $R$ Soc Trop Med Hyg (2007) 101(5):433-8. doi: 10.1016/j.trstmh.2006.08.008

135. Downs JA, Mguta C, Kaatano GM, Mitchell KB, Bang H, Simplice H, et al. Urogenital schistosomiasis in women of reproductive age in Tanzania's Lake Victoria region. Am J Trop Med Hyg (2011) 84(3):364-9. doi: 10.4269/ ajtmh.2011.10-0585

136. He YX, Chen L, Ramaswamy K. Schistosoma mansoni, S. haematobium, and S. japonicum: early events associated with penetration and migration of schistosomula through human skin. Exp Parasitol (2002) 102(2):99-108. doi: 10.1016/S0014-4894(03)00024-9

137. Kullberg MC, Pearce EJ, Hieny SE, Sher A, Berzofsky JA. Infection with Schistosoma mansoni alters Th1/Th2 cytokine responses to a non-parasite antigen. J Immunol (Baltimore Md: 1950) (1992) 148(10):3264-70.

138. Bourke CD, Nausch N, Rujeni N, Appleby LJ, Mitchell KM, Midzi N, et al. Integrated analysis of innate, Th1, Th2, Th17, and regulatory cytokines identifies changes in immune polarisation following treatment of human schistosomiasis. J Infect Dis (2013) 208(1):159-69. doi: 10.1093/infdis/ jis524

139. Allen JE, Adjei O, Bain O, Hoerauf A, Hoffmann WH, Makepeace BL, et al. Of mice, cattle, and humans: the immunology and treatment of river blindness. PLoS Negl Trop Dis (2008) 2(4):e217-e. doi: 10.1371/ journal.pntd.0000217

140. Hoerauf A, Brattig N. Resistance and susceptibility in human onchocerciasis-beyond Th1 vs. Th2. Trends Parasitol (2002) 18(1):25-31. doi: 10.1016/S1471-4922(01)02173-0

141. Kroidl I, Saathoff E, Maganga L, Makunde WH, Hoerauf A, Geldmacher C, et al. Effect of Wuchereria bancrofti infection on HIV incidence in southwest Tanzania: a prospective cohort study. Lancet (Lond Engl) (2016) 388 (10054):1912-20. doi: 10.1016/S0140-6736(16)31252-1

142. Kroidl I, Chachage M, Mnkai J, Nsojo A, Berninghoff M, Verweij JJ, et al. Wuchereria bancrofti infection is linked to systemic activation of CD4 and CD8 T cells. PLoS Negl Trop Dis (2019) 13(8):e0007623. doi: 10.1371/ journal.pntd.0007623
143. Arndts K, Deininger S, Specht S, Klarmann U, Mand S, Adjobimey T, et al. Elevated adaptive immune responses are associated with latent infections of Wuchereria bancrofti. PLoS Negl Trop Dis (2012) 6(4):e1611. doi: 10.1371/ journal.pntd.0001611

144. Babu S, Kumaraswami V, Nutman TB. Transcriptional control of impaired Th1 responses in patent lymphatic filariasis by T-box expressed in T cells and suppressor of cytokine signaling genes. Infect Immun (2005) 73(6):3394-401. doi: 10.1128/IAI.73.6.3394-3401.2005

145. Bernhard P, Makunde RW, Magnussen P, Lemnge MM. Genital manifestations and reproductive health in female residents of a Wuchereria bancrofti-endemic area in Tanzania. Trans $R$ Soc Trop Med Hyg (2000) 94(4):409-12. doi: 10.1016/S0035-9203(00)90123-8

146. Veldhoen M, Heeney JL. A helminth-mediated viral awakening. Trends Immunol (2014) 35(10):452-3. doi: 10.1016/j.it.2014.08.004

147. Lepique AP, Daghastanli KR, Cuccovia IM, Villa LL. HPV16 tumor associated macrophages suppress antitumor $\mathrm{T}$ cell responses. Clin Cancer Res (2009) 15(13):4391-400. doi: 10.1158/1078-0432.CCR-090489

148. Petrillo M, Zannoni GF, Martinelli E, Pedone Anchora L, Ferrandina G, Tropeano G, et al. Polarisation of Tumor-Associated Macrophages toward M2 Phenotype Correlates with Poor Response to Chemoradiation and Reduced Survival in Patients with Locally Advanced Cervical Cancer. PLoS One (2015) 10(9):e0136654. doi: 10.1371/journal.pone.0136654

149. Feng Q, Wei H, Morihara J, Stern J, Yu M, Kiviat N, et al. Th2 type inflammation promotes the gradual progression of HPV-infected cervical cells to cervical carcinoma. Gynecol Oncol (2012) 127(2):412-9. doi: 10.1016/ j.ygyno.2012.07.098

150. Xie F, Liu L-B, Shang W-Q, Chang K-K, Meng Y-H, Mei J, et al. The infiltration and functional regulation of eosinophils induced by TSLP promote the proliferation of cervical cancer cell. Cancer Lett (2015) 364 (2):106-17. doi: 10.1016/j.canlet.2015.04.029

151. Vicetti Miguel RD, Quispe Calla NE, Dixon D, Foster RA, Gambotto A, Pavelko SD, et al. IL-4-secreting eosinophils promote endometrial stromal cell proliferation and prevent Chlamydia-induced upper genital tract damage. Proc Natl Acad Sci (2017) 114(33):E6892-E901. doi: 10.1073/ pnas.1621253114

152. Jacobs BA, Chetty A, Horsnell WGC, Schafer G, Prince S, Smith KA. Hookworm exposure decreases human papillomavirus uptake and cervical cancer cell migration through systemic regulation of epithelial-mesenchymal transition marker expression. Sci Rep (2018) 8(1):11547. doi: 10.1038/ s41598-018-30058-9

153. Schäfer G, Graham LM, Lang DM, Blumenthal MJ, Bergant Marušič M, Katz AA. Vimentin Modulates Infectious Internalization of Human Papillomavirus 16 Pseudovirions. J Virol (2017) 91(16):e00307-17. doi: 10.1128/JVI.00307-17

154. Guess JC, McCance DJ. Decreased Migration of Langerhans Precursor-Like Cells in Response to Human Keratinocytes Expressing Human Papillomavirus Type 16 E6/E7 Is Related to Reduced Macrophage Inflammatory Protein-3 $\alpha$ Production. J Virol (2005) 79(23):14852-62. doi: 10.1128/JVI.79.23.14852-14862.2005

155. Pahne-Zeppenfeld J, Schröer N, Walch-Rückheim B, Oldak M, Gorter A, Hegde S, et al. Cervical cancer cell-derived interleukin-6 impairs CCR7dependent migration of MMP-9-expressing dendritic cells. Int $J$ Cancer (2014) 134(9):2061-73. doi: 10.1002/ijc.28549

156. Garcia-Iglesias T, del Toro-Arreola A, Albarran-Somoza B, del Toro-Arreola S, Sanchez-Hernandez PE, Ramirez-Dueñas MG, et al. NKp30, NKp46 and NKG2D expression and reduced cytotoxic activity on NK cells in cervical cancer and precursor lesions. Low BMC Cancer (2009) 9(1):186. doi: 10.1186/ 1471-2407-9-186

157. Zhou C, Tuong ZK, Frazer IH. Papillomavirus Immune Evasion Strategies Target the Infected Cell and the Local Immune System. Front Oncol (2019) 9 (682). doi: 10.3389/fonc.2019.00682

158. Loddenkemper C, Hoffmann C, Stanke J, Nagorsen D, Baron U, Olek S, et al. Regulatory (FOXP3+) $\mathrm{T}$ cells as target for immune therapy of cervical intraepithelial neoplasia and cervical cancer. Cancer Sci (2009) 100 (6):1112-7. doi: 10.1111/j.1349-7006.2009.01153.x

159. Kim KH, Greenfield WW, Cannon MJ, Coleman HN, Spencer HJ, Nakagawa M. $\mathrm{CD} 4+\mathrm{T}$-cell response against human papillomavirus type $16 \mathrm{E} 6$ protein is 
associated with a favorable clinical trend. Cancer Immunol Immunother: CII (2012) 61(1):63-70. doi: 10.1007/s00262-011-1092-5

160. Molling JW, de Gruijl TD, Glim J, Moreno M, Rozendaal L, Meijer CJ, et al. $\mathrm{CD} 4(+) \mathrm{CD} 25$ hi regulatory T-cell frequency correlates with persistence of human papillomavirus type 16 and $\mathrm{T}$ helper cell responses in patients with cervical intraepithelial neoplasia. Int J Cancer (2007) 121(8):1749-55. doi: $10.1002 / \mathrm{ijc} .22894$

161. al-Saleh W, Giannini SL, Jacobs N, Moutschen M, Doyen J, Boniver J, et al. Correlation of T-helper secretory differentiation and types of antigenpresenting cells in squamous intraepithelial lesions of the uterine cervix. J Pathol (1998) 184(3):283-90. doi: 10.1002/(SICI)1096-9896(199803) 184:3<283::AID-PATH25>3.0.CO;2-K

162. Clerici M, Merola M, Ferrario E, Trabattoni D, Villa ML, Stefanon B, et al. Cytokine production patterns in cervical intraepithelial neoplasia: association with human papillomavirus infection. J Natl Cancer Inst (1997) 89(3):245-50. doi: 10.1093/jnci/89.3.245

163. Bais AG, Beckmann I, Lindemans J, Ewing PC, Meijer CJLM, Snijders PJF, et al. A shift to a peripheral Th2-type cytokine pattern during the carcinogenesis of cervical cancer becomes manifest in CIN III lesions. J Clin Pathol (2005) 58(10):1096-100. doi: 10.1136/jcp.2004.025072

164. Lee B-N, Follen M, Tortolero-Luna G, Eriksen N, Helfgott A, Hammill H, et al. Synthesis of IFN- $\gamma$ by CD8+ T Cells Is Preserved in HIV-Infected Women with HPV-Related Cervical Squamous Intraepithelial Lesions. Gynecol Oncol (1999) 75(3):379-86. doi: 10.1006/gyno.1999.5587

165. Oh JE, Kim B-C, Chang D-H, Kwon M, Lee SY, Kang D, et al. Dysbiosis-induced IL-33 contributes to impaired antiviral immunity in the genital mucosa. Proc Natl Acad Sci (2016) 113(6):E762-E71. doi: 10.1073/pnas.1518589113

166. Oh JE, Oh DS, Jung HE, Lee HK. A mechanism for the induction of type 2 immune responses by a protease allergen in the genital tract. Proc Natl Acad Sci (2017) 114(7):E1188-E95. doi: 10.1073/pnas.1612997114

167. Sykes L, MacIntyre DA, Yap XJ, Teoh TG, Bennett PR. The Th1:th2 dichotomy of pregnancy and preterm labour. Mediators Inflamm (2012) 2012:967629. doi: 10.1155/2012/967629

168. Krishnan L, Guilbert LJ, Wegmann TG, Belosevic M, Mosmann TR. T helper 1 response against Leishmania major in pregnant C57BL/6 mice increases implantation failure and fetal resorptions. Correlation with increased IFNgamma and TNF and reduced IL-10 production by placental cells. J Immunol (Baltimore Md: 1950) (1996) 156(2):653-62.

169. Hurd H. Host fecundity reduction: a strategy for damage limitation? Trends Parasitol (2001) 17(8):363-8. doi: 10.1016/S1471-4922(01)01927-4
170. Kurtis JD, Higashi A, Wu HW, Gundogan F, McDonald EA, Sharma S, et al. Maternal Schistosomiasis japonica is associated with maternal, placental, and fetal inflammation. Infect Immun (2011) 79(3):1254-61. doi: 10.1128/ IAI.01072-10

171. McDonald EA, Cheng L, Jarilla B, Sagliba MJ, Gonzal A, Amoylen AJ, et al. Maternal infection with Schistosoma japonicum induces a profibrotic response in neonates. Infect Immun (2014) 82(1):350-5. doi: 10.1128/ IAI.01060-13

172. Ndibazza J, Muhangi L, Akishule D, Kiggundu M, Ameke C, Oweka J, et al. Effects of deworming during pregnancy on maternal and perinatal outcomes in Entebbe, Uganda: a randomized controlled trial. Clin Infect Dis (2010) 50 (4):531-40. doi: 10.1086/649924

173. Olveda RM, Acosta LP, Tallo V, Baltazar PI, Lesiguez JL, Estanislao GG, et al. Efficacy and safety of praziquantel for the treatment of human schistosomiasis during pregnancy: a phase 2, randomised, double-blind, placebo-controlled trial. Lancet Infect Dis (2016) 16(2):199-208. doi: 10.1016/S1473-3099(15)00345-X

174. Friedman JF, Olveda RM, Mirochnick MH, Bustinduy AL, Elliott AM. Praziquantel for the treatment of schistosomiasis during human pregnancy. Bull World Health Organ (2018) 96(1):59-65. doi: 10.2471/ BLT.17.198879

175. Blackwell AD, Tamayo MA, Beheim B, Trumble BC, Stieglitz J, Hooper PL, et al. Helminth infection, fecundity, and age of first pregnancy in women. Science (2015) 350(6263):970-2. doi: 10.1126/science.aac7902

176. Geiger SM, Alexander ND, Fujiwara RT, Brooker S, Cundill B, Diemert DJ, et al. Necator americanus and helminth co-infections: further downmodulation of hookworm-specific type 1 immune responses. PLoS Negl Trop Dis (2011) 5(9):e1280. doi: 10.1371/journal.pntd.0001280

Conflict of Interest: The authors declare that the research was conducted in the absence of any commercial or financial relationships that could be construed as a potential conflict of interest.

Copyright (๑) 2020 Chetty, Omondi, Butters, Smith, Katawa, Ritter, Layland and Horsnell. This is an open-access article distributed under the terms of the Creative Commons Attribution License (CC BY). The use, distribution or reproduction in other forums is permitted, provided the original author(s) and the copyright owner(s) are credited and that the original publication in this journal is cited, in accordance with accepted academic practice. No use, distribution or reproduction is permitted which does not comply with these terms. 